\title{
City Branding and Local SMEs: A Smart Specialisation Perspective
}

\author{
Cecilia Pasquinelli
}

\begin{abstract}
The growing literature on city branding has widely overlooked the relationship between firms and city brands. This paper analyses firms, with a focus on local SMEs as city image consumers and users, but it also draws attention to them as producers of city images. From a smart specialisation perspective, this analysis suggests that firms may contribute to a new wave of 'innovation brands' according to which the place-based approach to innovation is made visible and perceived locally and internationally. The city brand may represent a source of values and symbols that legitimise and help understand local smart specialisation rationale, hence fostering the path of innovation at local and regional scale.
\end{abstract}

Keywords: City Brand; Place Branding; SMEs; Smart Specialisation; Innovation

\section{Innovation and the 'Soft' Dimension of Competitiveness}

The 'soft dimension' of competitiveness, which, referring to the domain of symbols, perceived values and images standing for a city in people's minds, is argued to deserve attention in the debate on smart specialisation and innovation policies for regional development. It is argued that the soft dimension of competitiveness is particularly worthy of attention in the case of the smart specialisation since this is a place-based strategy aimed at boosting different and specific territorial innovation patterns which, from the perspective of this work, are supported by place reputation and images. The link between the smart specialisation approach and place branding, which tags the literature stream focusing on the place image and leverages a brand analogy, is an open field for investigation.

The smart specialisation strategy needs to make its place-based rationale explicit and recognizable both for a matter of legitimacy of the smart specialisation approach in the European policy arena, and for a matter of competitiveness of the pursued strategies in global markets (i.e. differentiation and positioning). Visibility of local distinctive vision and reputation building are in the picture of those territorial systems pursuing a smart specialisation that is strongly supported locally

\footnotetext{
* Research Fellow in Urban Studies, Gran Sasso Science Institute (cecilia.pasquinelli@gssi.infn.it)
} 
and distinctively positioned globally. An outward orientation of the smart specialisation policy process is deemed complementary to an analysis of regional assets and internal connections, so that there is a need to reflect on the position of the regional economy and its actors in global value chains (Bellini, Grillo 2012). As this paper will argue, there is a soft dimension to take into account as regards the positioning of products and processes and their path of differentiation and innovation, in line with the strengthening imperatives of intangible assets management imposed by an enlarging competition breadth and an inter-dependence of markets that facilitates comparison across companies, supplies and investments (Corniani 2010). High degrees of sophistication of corporate intangible assets are, in fact, fundamental condition for success in global markets (Brondoni 2010). Accordingly, the process of search and identification of 'vertical and non neutral logic of intervention' for a smart specialisation (Foray 2013) should not only consider the hard factors but also the soft factors of competitiveness. Soft factors, in other words, should not be overlooked throughout the 'learning process' (Foray et al. 2009) that leads to discovering those research and innovation field in which a region can excel.

Based on these premises, cities as pivots of regional smart specialisation strategies in the 'Europe of Cities' and discusses branding as part of city management processes, with special focus on the role of firms in building urban brands and, on the other hand, on the role of city brands in supporting firms' competitivity. Firms consume but also produce and circulate city images, and may contribute to a new wave of innovation brands, which support the place of innovation', i.e. a place where innovation is experienced, daily lived and consumed but also a place where 'innovations' are designed and made. Innovation brands, though based on a fairly universal idea or model of innovation, embody and communicate a territory and its vocation which needs to be made visible, perceived, 'felt' and generally understood.

\section{City Branding}

The building, exploitation and appropriation of city images are not new practice, yet branding geographic areas for alluring tourists, students, workers and investors, has seen fast and progressive sophistication over the last decades (Kavaratzis, Ashworth 2010). Place branding literature has been debating distinctiveness (or differentiation), affirming its centrality in global competition and arguing the capacity of the place's 'local character' to boost distinctive images, in opposition to placelessness and standardization (Bramwell, Rawding 1996). The principle of differentiation, which is fundamental for a long-term cultivation of brands (Fournier, Avery 2011), suggests a need to nurture distinctive urban features (Turok, Bailey 2004) and define a differential advantage (Turok 2009).

Several are, however, the limits of the principle of differentiation in city branding practice. This was evident in the analysis of innovation brands, aimed at fostering the reputation of the place where innovation is produced and consumed. Three following waves of city branding, respectively based on the models of the 'Silicon' place, the 'Creative' place and the 'Authentic' place, showed how city representation tends to fit with predefined scripts telling what an innovation hotspot 
is universally supposed to be and offer (Pasquinelli, Teräs 2011; Pasquinelli, Teräs 2013). The proliferation of 'clone cities' (Landry 2006; Hospers 2008) shows that a 'formula has emerged around the idea of differentiation' (Turok 2009); instead of triggering distinctive positioning, competition is likely to provoke 'recursive or serial monotony' according to which places' imageries tend to converge (Bramwell, Rawding 1996). The mimetic process of city branding - mirroring what Czarniawska (2002) called 'mimetic representation' i.e. reproducing global ideal types at the local scale (see below) - might be part of an utilitaristic accreditation strategy of city branding (Ooi 2014), according to which developing a brand 'similar' to the established leaders allows the city to enter target arenas of competition, such as the one of global innovation hotspots.

Innovation is, in fact, an arena for cities' competition. An example is the competition to be leading smart cities ${ }^{1}$ and it is evident how cities (local governments) make efforts to be ranked higher and higher according to the Smart City Indexes which are mushrooming nationally and internationally (e.g. European Smart Cities ranking by Vienna University of Technology, Griffinger et al. 2010, or the Smart City Index by between SpA for the Italian context; these are just two of the many examples). A form of 'smartification' is in action (Peacock 2011), even though smart-city standards are not clearly defined and doubtfully achieved by the (often) self-nominated smart cities. There is a "difference between a city actually being intelligent, and it simply lauding a smart label" (Hollands 2008).

Branding, however, should not be simply considered as an act of 'lauding a label'. Innovation brands raise the reputation of the city from two different perspectives. First, as a place where technologies are consumed and where the related innovations are experienced through innovative practices of urban living. The city brand fosters particular styles of consumption (Arvidsson 2011) and shapes distinctive contexts for consumption and rituals (Pike 2011), throughout embedding the images of the vibrant, liveable, technological, sustainable city. The brand plays as catalyst of the 'culture of the community', determining how readily new ideas are accepted and providing a vision as well as a narrative that helps a community understand an ever changing world (Intelligent Community Forum 2013).

Secondly, city branding is functional to the building of city reputation as place where innovation is produced. That is, the brand reinforces the images of the place of talent, creativity and production that may trigger a 'self-fulfilling prophecy' concerning the path of economic development (Bellini 2004). This side of the city brand tends to be overlooked by both academics and practitioners, as we shall see in the next sections.

\section{City Branding as Process of City Management}

Beyond its marketing functions, urban branding is interpreted as a communicative process underlying and enabling urban strategy-making (Pasquinelli 2014). Branding consists in a city representation according to which urban problems - as well as possible solutions - are explained, communicated, shared and understood. City representation is part of city management processes given the strong influence of representation on decision-making and, consequently, on the urban reality (Czarniawska 2002). To reach an insight in local decision-making, it is thus 
important to analyse how cities are represented. Their representation usually tends to oscillate between 'the same' and 'the unique' because of - on the one hand - a need to refer to models that are sources of legitimation and identity formation ('the same') and, on the other hand, because of an unavoidable local resistance to globalization ('the unique'), as Czarniawska (2002) observed.

It is worth adding a reference to the role of 'fashion' in (city) management (Czarniawska 2005), meaning the global traveling of ideas and models (Czarniawska, Sevón 1996). 'Imitation waves' consecrate fashion in management but at the same time imitation changes fashion according to unavoidable processes of translation, that is, a constant transformation of ideas and models occurring when these are reproduced elsewhere ("setting something into a new place means constructing it anew", Czarniwaska 2005).

A practice becomes fashion when it is considered as superior solution on the basis of quality or geographical provenance determining its prestige (or 'reverential imitation', Czarniwaska 2005); when it has a power-symbolic superiority or when it is supported by a corollary of well established ideas that favour its understanding and circulation (Czarniawska 2005). However, not only ideas and practices travel but also names and labels do (Czarniawska 2005), so that what is called in the same way often tags very different practices that receive legitimation and reputation from the appropriated label.

In the analysis of city brands it is reasonable to ask (a) if there is an original model (trend-setter) that is followed, imitated and replicated, (b) what has been translated and transformed during the traveling of the brand concept and (c) to what extent the replication succeeds in embedding urban practices or, instead, it is simply a label. "Management is as fashion-prone as clothing industry!" (Czarniwaska 2005) and, especially in the case of city management, we should reflect on what this may imply. What are the benefits and what the costs of 'fashion'?

Czarniawska's arguments on the role of fashion in management help explain 'the unique' and the constant evolution and translation of the city brand. Uniqueness, distinctiveness and authenticity are salient to innovation brands, and even more salient in the frame of smart specialisation strategies where the unique/authentic/distinctive brand is supposed to mirror a place-based strategy rooted in the reinterpretation of local vocations. Subsequent fashion's translations produce difference (Czarniawska 2005) also depending on the 'carriers' and 'receivers' enacting a relational and active process of reception and adaptation to a specific context (Powell et al. 2005). Powell et al. (2005) proposed differential patterns of receptivity: one characterising the 'enthusiastic adopter' receiving fashion uncritically, another characterising the 'active resistor' refusing the traveling model or practice, and the 'engaged translator', adopting yet adapting the traveling fashion. Figure 1 shows four possible ways to receive and put in practice a smart city brand which is here argued to have become fashion in innovation management (Peacock 2011). 
Figure 1: Smart City (Brand) Strategy:The Role of Fashion in City Management

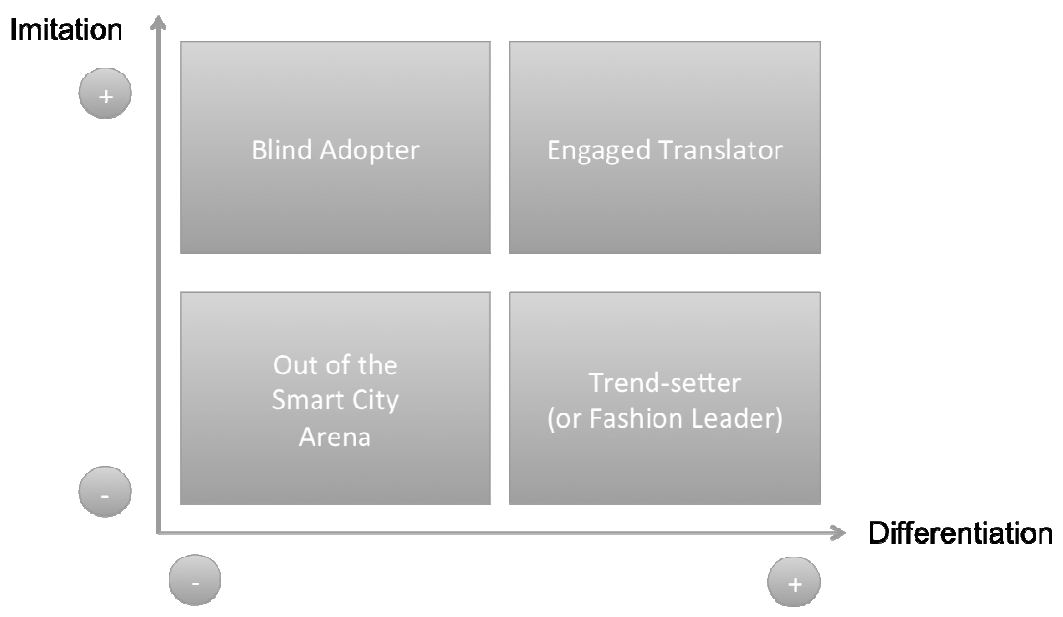

While a degree of 'sameness' is necessary to enter the competitive arena, a 'blind' or non-critical adoption of the smart city script can result in a poor strategy where little distinctiveness mirrors a lack of place-based vision for the local path of development. While cities are trend-setters either for their rational/functional superiority or for their power-symbolic superiority (see above), high degree of differentiation characterises also those urban contexts that succeed in translating an imitated model according to local needs, expectations and paths of development. These are the 'engaged translators' that constantly transform the brand. The next section will discuss about those actors that contribute to the 'engaged translation'. As we shall see, local firms - including SMEs - may play a key role in shaping the city brand, throughout an engaged translation echoing the smart specialisation rationale.

\section{The Relationship between Local Firms and City Branding}

What are the processes and, especially, what the stakeholders boosting competitive city brands? City branding is often defined as "conscious attempt of governments to shape a specifically designed place identity and promote it to identified markets" (Kavaratzis, Ashworth 2010). The principle of coordination (Dinnie et al. 2010) is at the core of city branding and the participation of citizens and different stakeholders is said necessary to enhance brand quality (Eshuis et al. 2014). Participation, however, often ends up being a process of persuasion throughout politicking, i.e. aligning different voices to the official city brand (Ooi 2004) in order to minimize different brand interpretations (Zhang, Zhao 2009). And even if thinking of the city brand as result of collective action (Pasquinelli 2014), the city brand seems to coincide with a monolithic object emerging from a collective, shared and negotiated process where the public actor plays a significant role of orchestration. In contrast, a network of stakeholders - outside institutionalized circuits of city brand building - participate in creating city images by consuming, producing and circulating them. As Jansson and Power (2010) put it, the place brand is built throughout circuits that are activated by third parties 
while building their own brands. City branding is not just and not only a coordinated and strategic process but also a multi-directional and 'spontaneous' dynamics triggered by all those stakeholders that, while referring to (i.e. establishing a relationship with) the city, contribute to build city images and reputation. In Czarniaskwa's words (2002), we have to focus on the 'image in use' to analyse city representation, and not simply on those images strategically shaped by city marketers. The 'image in use' informs on the on-going processes of city management. At the same time, as Czarniawska (2002) explains, the production of difference among places and organizations does not depend upon the type of images that are 'designed' and 'sent' but upon those in use, while use implies a constant reconstruction and work of representation.

Among those actors that 'use' city images - constantly changing, translating and transforming them - we choose to focus on firms, whose role in city branding is too often overlooked. Firms, first of all, are consumers of city images. Think for instance of investors who, in the face of strategic decision-making concerning international expansions (Pasquinelli 2014b), 'consume' city brands to simplify information and receive sense of orientation (Jacobsen 2009). There is an affective side in the creation of awareness and knowledge about a place and both economic and emotional variables influence corporate decision-making (Papapdopoulos 2004). Firms, then, appropriate 'monopoly rents' from city images (Tokatli 2013) to boost their competitiveness (Power, Scott 2004) and to enhance the perception of their products' quality (Jansson, Waxell 2011). This paper wants to suggest that local firms' product brands draw support from the city brand, since this latter can foster what marketing management refers to as the establishment of a relationship with given markets, and can improve the value of such relationship in a way that a non-transferable intangible asset is created for the company (Brondoni 2001; Brondoni 2010).

Firms are producers of city images. The way in which firms behave, the type and quality of production they deliver and, hence, the type of markets they are in, their performance and their history create symbolic associations for their place of origin or, rather, for the place they are perceived to come from or being originated in. To make an example, global technology players, e.g. Google and Apple, boost an image-making that does not only build their own brands but also enriches the brand of the territory hosting them. In the field of cultural industries, it was argued that fashion, luxury and design firms can play as 'factors of appeal' hence contributing to develop alternative models of immaterial consumption within a specific city or a specific area of it, with significant impact on the territory (Arrigo 2011). These arguments complement the more traditional 'Made in' and 'Designed in' discussion highlighting the value that firms appropriate by locating in a region: there is an evident need to further reflect on the value(s) that territories draw from the presence of flagship companies and investments. Moreover, local firms contribute to the circulation of the city brand by means of internationalization that not only position firms' products and services abroad but often broadcast the brand associated to firms' geographical origins. Firms' global presence boosts the circulation of the city brand thus favouring its translation and continuous transformation. 


\section{Technology and City Brand Building Made in Florence. The Case of Centrica}

Centrica is an ICT company based in Florence, Italy. It was selected to exemplify the activity of an 'engaged translator' contributing to create innovative city images and circulating them worldwide, throughout the routes of the firm's internationalization. Centrica actively consume, produce and circulate the 'smart images' of the city of Florence, adding to the well-rooted images of the city of art. At the same time Centrica translates the smart city model through its activities, in a local way, i.e. responding to local needs, criticalities and challenges. This case wants to suggest the intertwining of local unique vocation for arts and culture with emerging local entrepreneurship engaged with new technologies as potential path for a local smart specialisation, which, in this case, is also rooted in a 'soft dimension' of local competitiveness.

A brief overview of the case and context. The city of Florence (about 380.000 inhabitants) is the regional capital of Tuscany (Italy). Florence is a brand of art and culture and it is integral part of Tuscany's international image. Tourism is an exceptional driver of international visitors to Florence, one of the most visited art cities in Italy. Beside tourism, Florence is Tuscany's 'high-tech capital', with $33.9 \%$ of the region's businesses, $36.5 \%$ of employees, and $47 \%$ of turnover in the high-tech field ${ }^{2}$. The area is characterized by a specialisation in biomedical and pharmaceutical life-science sectors, in optoelectronics and photonics, in mechanical engineering for energy and the environment, and in ICT ${ }^{3}$. The ICT industry in Florence has entered the field of technologies and software for the preservation, dissemination and enhancement of cultural heritage and of intelligent, integrated regional data and information management in a smart city context. The sector produces a variety of products including, for instance, digital imaging, virtual reality models, 3D systems, immersive multimedia interfaces, smart video surveillance, remote sensing, artificial vision systems and digital libraries.

As said, in line with a smart specialisation rationale, the envisioning of local vocation (i.e. cultural heritage) seems to project the city in fast growing global markets. A recent place marketing initiative of the Municipality of Florence, which targeted investors and potential start-ups in the field of ICT for cultural heritage (among other industries), showed an effort to exploit the opportunities offered by technologies and global markets. Florence features a longstanding path in the development of technologies for the preservation of cultural assets, in particular laser technologies enabling major progresses in the field of materials conservation. Favourable conditions characterizing the urban context have stimulated design and production of laser applications for cultural heritage, owning to the presence of an art restoration cluster (Lazzeretti 2004; Lazzeretti et al. 2011) and to photonics and optoelectronics research and production centres. Tuscany is home to the Distretto 
Tecnologico Toscano per i Beni Culturali e la Città Sostenibile (Tuscany District for Cultural Heritage Technologies and Sustainable Cities, DiT-BeCS), which brings together regional actors operating in the ICT sectors, particularly clustered in the Florentine area. The operating core of DiT-BeCS is the Urban Park of Innovation Le Murate in Florence historical centre, with spaces dedicated to enterprises and research activities related to cultural heritage. The Urban Park also hosts the Nemech Laboratory (New Media for Cultural Heritage), the regional centre for the application of new technologies to cultural heritage, which is part of the Media Integration and Communication Centre. This is a centre of national excellence of the University of Florence, specialising in new media, with a focus on interpretation, processing and transmission of images, artificial vision, cultural heritage and multimedia technologies.

$\square$ In the 'smart city' national rankings, Florence took $2^{\text {nd }}$ spot in Italy for smart government and the $4^{\text {th }}$ for smart mobility ${ }^{4}$. Efforts were made to set up an advanced broadband infrastructure and the Municipality has invested in the development of a platform for tourism and city information management: "in such a rich area of artistic, tourism and cultural resources aiming to continuously expand its economy of cultural heritage, the development of urban IT systems was deemed fundamental, with an exponential growth in the exchange of content, interactive services (bookings and purchases) and social networking opportunities" $"$.

Centrica is a small company (about 10 employees) located in the Urban Park of Innovation. It designs and develops innovative solutions in the sectors of ultrahighresolution digital imaging, interactive visual communication and knowledge management. It is active in cultural heritage, tourism, fashion and luxury goods, safety and anticounterfeiting through a spin-off, named ViDiTrust. Founded in 1999 from a group of electronic engineers graduated at Florence University, Centrica's mission concerns the revitalization of cultural heritage and draws attention to its role in the Italian economic system through the use and development of digital technologies. "Italy - says Centrica $\mathrm{CEO}^{6}$ - has a unique opportunity: it can exploit its own natural vocation in culture to position in the global market of technologies for the enhancement of cultural heritage. This opportunity is now to be taken". One example of Centrica's products is XLimage ${ }^{\circledR}$ which allows a "visual experience with immediate benefits like company or cultural organization brand recognition, perception of the product's quality"7. The Regione Toscana (the regional authority), the Scala Group, the National Library of Florence, the Italian Cultural Heritage Minister as well as the Royal Library of Belgium and the UNESCO use this product.

Centrica produce innovative city images since drawing a clear link between technology production and the Florence reality. Centrica's products and their quality, the occupied markets and its geographical provenance create symbolic associations benefiting Centrica as well as its place of origin, i.e. Florence.

Uffizi Touch ${ }^{\circledR}$ is the world's first product to hold in the form of extremely high-resolution digital interactive paintings the entire artistic 
heritage of the Uffizi Gallery in Florence. The app allows a virtual visit of one of the world's most famous museums through an immersive experience enabling the fruition of the artworks and an exploration of every detail. "It is an exclusive privilege to visit or own the entire collection of one of the most famous museums - the dedicated website says $^{8}$ - and it can be a useful tool to start organizing a visit to Florence".

There is an evident consumption of the city images in the form of Centrica's appropriation of the 'monopoly rents' deriving from the use of Florence image, fostering the firm's competitiveness in the field of cultural heritage. Another example of Centrica's products is a platform for the urban context where a number of content providers can integrate their information. The idea is that tourists and citizens need to have the best possible experience of and gather knowledge on what they have in their proximity while walking in the city. The intrusive presence of technologies is designed to enable travellers' emotional encounter with the city. As a matter of fact, information technologies create emotional pressure points in the city and the immersive Internet (Teigland and Power 2013) enhances the urban experience.

Centrica (and its products) is carrier of Florence images, which circulate throughout the firm's internationalization, as shown in Table 1. The city images circulate while diffusing a Florentine model based on a capacity to link the artistic and cultural wealth of the city with technological expertise and know how to manage, enhance and disseminate cultural assets. Florence image of "the city of art" gives a power-symbolic superiority in the field of technologies for cultural heritage benefiting local firms. Table 1 lists those moments in which Centrica has co-produced Florence city brand, while making it travel, be consumed and reinterpreted by multiple audiences. While the image of Florence travels with the traveling of Centrica's products and services, Centrica contributes to renew the perception of Florence as a 'place of innovation' today (not only in its unique past), meaning a place where technology is produced and designed.

Table 1: Summary of Centrica's International Activities (a selection)

\begin{tabular}{|c|c|l|}
\hline Year & Where & \multicolumn{1}{|c|}{ Centrica's activities } \\
\hline 2010 & $\begin{array}{l}\text { Shanghai, } \\
\text { China }\end{array}$ & $\begin{array}{l}\text { Centrica is selected as part of 'Italia degli } \\
\text { Innovatori for participating in the Italian } \\
\text { Pavilion at the Expo in Shanghai. Centrica } \\
\text { presents Uffizi Touch. } \\
\text { Centrica organized the exhibition 'Uffizi } \\
\text { Virtuale' based on Uffizi Touch. The exhibition } \\
\text { registered 50,000 visitors. }\end{array}$ \\
\hline 2011 & Tokyo, Japan & $\begin{array}{l}\text { Centrica organizes in collaboration with Hitachi } \\
\text { (a Japanese multinational company in } \\
\text { engineering and electronics) the exhibition } \\
\text { 'Uffizi Virtual Museum' at the Italian Cultural } \\
\text { Institute of Tokyo }\end{array}$ \\
\hline
\end{tabular}




\begin{tabular}{|c|c|l|}
\hline 2012 & $\begin{array}{c}\text { Berlin, } \\
\text { Germany }\end{array}$ & $\begin{array}{l}\text { Centrica participated in the Smart City summit } \\
\text { presenting 'Smart Cultural Heritage'. }\end{array}$ \\
\hline 2013 & Beijing, China & $\begin{array}{l}\text { Centrica is partner of the Italian Living } \\
\text { Experience, a space dedicated to creativity and } \\
\text { Italian excellence in the district 751, a central } \\
\text { reference in the field of design and fashion in the } \\
\text { Chinese capital. Centrica provided the technical } \\
\text { support to making it available the information } \\
\text { on the initiative partners through digital images. } \\
\text { Centrica exhibits "Renaissance in Florence. } \\
\text { Masterpieces and Protagonists". The exhibition } \\
\text { inaugurates a permanent museum space, 'Space } \\
\text { Italy', at the National Museum of China in } \\
\text { Tiananmen Square. }\end{array}$ \\
\hline
\end{tabular}

\section{Final Remarks and Emerging Issues}

The growing literature on city branding has widely overlooked the relationship between firms and city brands, which, instead, deserves much attention in the light of the soft dimension of competitiveness. This paper took into account firms as city image consumers and users, but it also drew attention to firms as producers of city images. From a smart specialisation perspective, this analysis suggests that firms may contribute to a new wave of innovation brands according to which the placebased approach to innovation is made visible and generally perceived locally and internationally. The city brand may represent a source of values and symbols that legitimize and help understand local smart specialisation rationale, thus fostering the path of innovation at a local scale.

The case of Centrica and the city of Florence provided an opportunity to discuss how culture and technology merge into the city brand circulating with Centrica's internationalization steps, thus suggesting a need to consider the proactive role of individual firms in city branding with great attention. This paper interpreted the analysed case in relation to the firm's engaged translation of the 'smart city' brand, based on local needs, challenges and opportunities, with potential distinctive positioning of the city among global innovation hotspots. Consumption, production and circulation of city images are modalities of reputation building, strengthening and rejuvenating city images as place where technology is produced nowadays.

There is an evident co-branding frame linking the city and the firm, making both partners gain in reputation. Centrica is carrier of Florence images but also an active producer of values and meanings. On the other hand, Centrica exploits the place of origin - the Florence brand - to get accreditation, reputation and international attention in the field of cultural heritage. This seems to be a win-win branding strategy. It is worth reflecting on the fact that SMEs like Centrica can play a vital role in terms of city branding and can have the power to shape and circulate valuable city images. Their small size is largely compensated by high degrees of specialisation in niche segments - often overlooked by global technology player as well as by their ability to diversify their products by defining tailor made solutions targeting specific needs of specific places. 
Finally, this case helps understand potential modalities in which the smart specialisation rationale can take shape at a micro-scale. The process can coincide with the development of applications that, coming from general-purpose technologies (in the ICT sector, in the analysed case) are introduced into an important domain of the regional economy (Foray et al. 2009), i.e. cultural heritage. Logic of "differentiation in a narrow sense" (Foray 2013) seems to describe this case, where synergies among existing activities, competences, skills and soft factors of competitiveness, such as images, symbols and perceived values, materialize.

\section{Bibliography}

Arrigo Elisa (2011) Fashion, Luxury and Design: Store Brand Management and Global Cities' Identitites, Symphonya. Emerging Issues in Management (symphonya.unimib.it), n. 1, pp. 55-67. http://dx.doi.org/10.4468/2011.1.06arrigo

Arvidsson Adam (2011) Creativity, Brands, Finance and beyond: Notes towards a Theoretical Perspective on City Branding, Andy Pike (ed.), Brands and Branding Geographies, Edward-Elgar, Cheltenham.

Bellini Nicola (2004) Territorial Governance and Area Image, Symphonya. Emerging Issues in Management (symphonya.unimib.it), n. 1, pp. 14-26.

http://dx.doi.org/10.4468/2004.1.03bellini

Bellini Nicola, Grillo Francesco (2012) The Strategies for Research and Innovation of the Italian Regions within the Perspective of 'Smart Specialization', European Commission, Directorate General Regional Policy, Brussels.

Bramwell Bill, Rawding Liz (1996) Tourism Marketing Images of Industrial Cities, Annals of Tourism Research, vol. 23, n. 1, pp. 2201-2221. http://dx.doi.org/10.1016/0160-7383(95)00061-5

Brondoni Silvio M. (2001) Brand Policy and Brand Equity, Symphonya. Emerging Issues in Management (symphonya.unimib.it), n. 1, pp. 5-25. http://dx.doi.org/10.4468/2001.1.02brondoni

Brondoni Silvio M. (2010) Ouverture de 'Intangible Assets \& Global Competition', Symphonya. Emerging Issues in Management (symphonya.unimib.it), n. 2, pp. 1-5. http://dx.doi.org/10.4468/2010.2.01ouverture

Corniani Margherita (2010) The Cost of Managing Intangibles in Global Markets, Symphonya. Emerging Issues in Management (symphonya.unimib.it), n. 2, pp. 52-66. http://dx.doi.org/10.4468/2010.2.05corniani

Czarniawska Barbara (2002) A Tale of Three Cities: or the Globalization of City Management, Oxford University Press, Oxford.

Czarniawska Barbara (2005) Fashion in Organizing, Barbara Czarniawska, Guje Sevón (eds.), Global Ideas: how Ideas, Objects and Practices Travel in a Global Economy, Copenhagen Business School Press, Malmo.

Czarniawska Barbara, Sevón Guje (1996) Translating Organizational Change De Gruyter, Berlin.

Dinnie Keith, Melewar T.C., Seidenfuss Kai-Uwe, Musa Ghazali (2010) Nation Branding and Integrated Marketing Communications: an ASEAN Perspective, International Marketing Review, vol. 27 , n. 4 , pp. 388-403.

http://dx.doi.org/10.1515/9783110879735

Dinnie Keith (2009) Book Review. Destination Branding for Small Cities: The Essentials for Successful Place Branding, Journal of Brand Management, vol. 17, pp. 159-161. http://dx.doi.org/10.1057/bm.2008.38

Eshuis Jasper, Klijn Erik-Hans, Braun Erik (2014) Place Marketing and Citizen Participation: 
Branding as Strategy to Address the Emotional Dimension of Policy Making?, International Review of Administrative Sciences, vol. 80, n. 1, pp. 151.

http://dx.doi.org/10.1177/0020852313513872

Foray Dominique (2013) Smart Specialization and the New Industrial Policy. Policy Brief N. 8. Innovation for Growth - i4g, , European Commission, Brussels.

Foray Dominique, Paul A. David, Hall Bronwyn (2009) Smart Specialization - The Concept. Knowledge Economists Policy Brief N. 9, June 2009.

Fournier Susan, Avery Jill (2011) The Uninvented Brand, Business Horizons, vol. 54, pp. 193-207.

Giffinger Rudolf, Haindlmaier Gudrun, Kramar Hans (2010) The Role of Rankings in Growing City Competition, Urban Research \& Practice, vol. 3, n. 3, pp. 299-312

http://dx.doi.org/10.1080/17535069.2010.524420

Herstein Ram, Jaffe Eugene D. (2008) The Children's City - The Transition from a Negative to a Positive City Image, Place Branding and Public Diplomacy, vol. 4, n. 1, pp. 76-84.

http://dx.doi.org/ 10.1057/palgrave.pb.6000082

Hollands Robert J. (2008) Will the Real Smart City Please Stand Up?, City: Analysis of Urban Trends, Culture Theory, Policy Action, vol. 12, n. 3, pp. 303-320. http://dx.doi.org/10.1080/13604810802479126

Hospers Gert-Jan (2008) Governance in Innovative Cities and the Importance of Branding, Innovation: Management, Policy \& Practice, vol. 10, n. 2/3, pp. 224-234. http://dx.doi.org/10.5172/impp.453.10.2-3.224

Intelligent Community Forum (2013) Community as Canvas. The Power of Culture in the Emergence of Intelligent Community, (last access December 2014).

http://www.intelligentcommunity.org

Jacobsen Bjorn P. (2009) Investor-Based Place Brand Equity: a Theoretical Framework, Journal of Place Management and Development, vol. 2, n. 1, pp. 70-84.

http://dx.doi.org/10.1108/17538330910946029

Jansson Johan, Power Dominic (2010) Fashioning a Global City: Global City Brand Channels in the Fashion and Design Industries, Regional Studies, vol. 44, n. 7, pp. 889-904.

http://dx.doi.org/10.1080/00343400903401584

Jansson Johan, Waxell Anders (2011) Quality and Regional Competitiveness., Environment and Planning A, vol. 43, n. 9, pp. 2237-2252.

http://dx.doi.org/10.1068/a4469

Kavaratzis Mihalis, Ashworth Gregory (2010) Place Branding: where do we Stand?, Gregory Ashworth, Mihalis Kavaratzis (eds.), Towards Effective Place Brand Management: Branding European Cities and Regions, Edward Elgar, Cheltenham.

http://dx.doi.org/10.4337/9781849806398.00007

Kavaratzis Michalis, Ashworth Gregory (2005) City Branding: An Effective Assertion of Identity or a Transitory Marketing Trick? Tijdschrift voor Economische en Sociale Geografie, vol. 96, n. 5, pp. 506-514.

http://dx.doi.org/10.1111/j.1467-9663.2005.00482.x

Lazzeretti Luciana (2004) Art Cities, Cultural Districts and Museums, Firenze University Press, Florence.

Lazzeretti Luciana, Capone Francesco, Cinti Tommaso (2011), Open Innovation in City of Art: The Case of Laser Technologies for Conservation in Florence, City, Culture \& Society, vol. 2, n. 1, pp. 159-168.

http://dx.doi.org/10.1016/j.ccs.2011.09.001

Ooi Can-Seng (2004) Poetics and Politics of Destination Branding: Denmark, Scandinavian Journal of Hospitality and Tourism, vol 4, n. 2, pp. 107-121.

http://dx.doi.org/10.1080/15022250410003898

Ooi Can-Seng (2014) The Making of the Copy-Cut City: Accreditation Tactics in Place Branding, in Per Olof Berg, Emma Björner (eds.), Branding Chinese Mega-Cities: Policies, Practices and 
Positioning, Edward Cheltenham, pp. 232-248.

Papadopoulos Nicolas (2004) Place Branding: Evolution, Meaning and Implications, Place Branding and Public Diplomacy, vol. 1, n. 1, pp. 36-49.

http://dx.doi.org/10.1057/palgrave.pb.5990003

Pasquinelli Cecilia (2014a) Branding as Collective Strategy-Making: the Formation of NewcastleGateshead's Organizational Identity, Urban Studies, vol. 52, n. 4, pp. 727-743.

http://dx.doi.org/10.1177/0042098013493025

Pasquinelli Cecilia (2014b) Innovation Branding for FDI Promotion: Building the Distinctive Brand, in Per Olof Berg, Emma Björner (eds.), Branding Chinese Mega-Cities: Policies, Practices and Positioning, Edward Elgar, Cheltenham, pp. 207-219.

http://dx.doi.org/10.4337/9781783470334.00024

Pasquinelli Cecilia, Teräs Jukka (2013) Branding Knowledge-Intensive Regions: A Comparative Study of Pisa and Oulu High-Tech Brands, European Planning Studies, vol. 21, n. 1, pp. 16111629.

http://dx.doi.org/10.1080/09654313.2012.722962

Pasquinelli Cecilia, Teräs Jukka (2011) Branding Peripheral Knowledge-Intensive Regions. An Insight into International Innovation Brands, Regional Insights, vol. 2, n. 2, pp. 9-11.

http://dx.doi.org/10.1080/20429843.2011.9727921

Peacock Hayley (2012) Cities in Competition: Branding The Smart City, available at (last access November 2012).

http://www.tedxamsterdam.com/2012/cities-in-competition-branding-the-smart-city/

Pike Andy (2011) Placing brands and Branding: a Socio-Spatial Biography of Newcastle Brown Ale, Transactions of the Institute of British Geographers, vol. 36, n. 2, pp. 206-222.

http://dx.doi.org/10.1111/j.1475-5661.2011.00425.x

Powell Walter W., Gammal Denise L., Simard Caroline (2005) Close Encounters: The Circulation and Reception of Managerial Practices in the San Francisco Bay Area Nonprofit Community, in Barbara Czarniawska, Guje Sevón (eds.), Global ideas. How Ideas, Objects and Practices Travel in the Gglobal Economy, Copenhagen Business School Press, Malmo.

Power Dominic, Scott Allen J. (2004) (eds.) Cultural Industries and the Production of Culture, Routledge, London.

Tiezzi Ilaria (2010) Renewing the Image of an Art City. An International Benchmarking Study,Boston Consulting Group, Polistampa, Florence.

Tokatli Nebahat (2013) Doing a Gucci: the Transformation of an Italian Fashion Firm into a Global Powerhouse in a 'Los Angelis-izing' World, Journal of Economic Geography, vol. 13, n. 2, pp. 239-255.

http://dx.doi.org/10.1093/jeg/lbs050

Turok Ivan (2009) The Distinctive City: Pitfalls in the Pursuit of Differential Advantage, Environment and Planning A, vol. 41, n. 1, pp. 13-30.

http://dx.doi.org/10.1068/a37379

Turok Ivan, Bailey Nick (2004) Twin Track Cities? Competitiveness and Cohesion in Glasgow and Edinburgh, Progress in Planning, vol. 62, n. 3, pp. 135-204. http://dx.doi.org/10.1016/j.progress.2004.04.001

Zhang Li, Zhao Simon Xiaobin (2009) City Branding and the Olympic Effect: A Case Study of Beijing, Cities, vol. 26, n.5, pp. 245-254.

http://dx.doi.org/10.1016/j.cities.2009.05.002 


\section{Notes}

1 It is important to distinguish two different notions of smartness. Concerning the "smart specialization", smartness refers to a place-based vision for economic development through an update of local vocations, attempting to exploit new opportunities opened by technologies and global markets. Concerning "smart cities", smartness refers to the diffusion of technologies, and in particular information technologies, for enabling efficient, sustainable and competitive (i.e. smart) communities within an urban context that takes a shape of an 'urban network of networks'.-As also this paper will contribute to show, smart city strategy may have important aspects in common with local smart specialization, but this necessarily implies an extention of the notion of smart city to a vision for local economic development something that does not seem to be in focus among either policy makers or scholars.

${ }^{2}$ Observatory of Tuscan Hight Tech Firms (2013) Alta Tecnologia in Toscana. IV Rapporto Annuale [High Technology in Tuscany. IV Annual Report]. Unioncamere and Institute of Management, Scuola Superiore Sant'Anna.

${ }^{3}$ Cittá di Firenze: A Report for Investors: Technologies for Cultural Heritage. Culture meets Business in Florence, Municipality of Florence, 2014.

${ }^{4}$ Report by between 2013 cited in A Report for Investors: Technologies for Cultural Heritage. Culture meets Business in Florence, Municipality of Florence, 2014.

${ }^{5}$ Cittá di Firenze: A Report for Investors: Technologies for Cultural Heritage. Culture meets Business in Florence, Municipality of Florence, 2014.

6 Source: http://www.cotec.it/it/2011/04/lopportunita-dellarte-digitale/, last access 20 January 2015 .

${ }^{7}$ Source: http://www.centrica.it/products/xlimage-2/, last access 20 January 2015.

${ }^{8}$ Source: http://www.uffizitouch.com, last access 1 September 2014. 